\title{
Application of Life Cycle Assessment in the Environmental Study of Sustainable Ceramic Bricks Made with 'alperujo' (Olive Pomace)
}

\author{
Ana B. López-García ${ }^{1}{ }^{\mathbb{D}}$, Teresa Cotes-Palomino ${ }^{1} \mathbb{D}$, Manuel Uceda-Rodríguez ${ }^{1} \mathbb{D}$, José Manuel Moreno-Maroto ${ }^{1} \mathbb{D}$, \\ Carlos Javier Cobo-Ceacero ${ }^{1}$, N. M. Fernanda Andreola ${ }^{2}$ and Carmen Martínez-García 1,*D
}

1 Department of Chemical, Environmental and Materials Engineering, Higher Polytechnic School of Linares, Scientific and Technological Campus of Linares, University of Jaen, 23700 Linares (Jaén), Spain; ablopez@ujaen.es (A.B.L.-G.); mtcotes@ujaen.es (T.C.-P.); muceda@ujaen.es (M.U.-R.); jmmaroto@ujaen.es (J.M.M.-M.); cjcobo@ujaen.es (C.J.C.-C.)

2 Department of Engineering 'Enzo Ferrari', University of Modena and Reggio Emilia, Via Pietro Vivarelli 10, 41125 Modena, Italy; fernandanora.andreola@unimore.it

* Correspondence: cmartin@ujaen.es; Tel.: +34-953-648-548

check for updates

Citation: López-García, A.B.; Cotes-Palomino, T.; Uceda-Rodríguez, M.; Moreno-Maroto, J.M.; Cobo-Ceacero, C.J.; Andreola, N.M.F.; Martínez-García, C. Application of Life Cycle Assessment in the Environmental Study of Sustainable Ceramic Bricks Made with 'alperujo' (Olive Pomace). Appl. Sci. 2021, 11, 2278. https://doi.org/10.3390/ app11052278

\section{Academic Editor:}

Antonella D'Alessandro

Received: 12 February 2021

Accepted: 2 March 2021

Published: 4 March 2021

Publisher's Note: MDPI stays neutral with regard to jurisdictional claims in published maps and institutional affiliations.

Copyright: (c) 2021 by the authors. Licensee MDPI, Basel, Switzerland. This article is an open access article distributed under the terms and conditions of the Creative Commons Attribution (CC BY) license (https:/ / creativecommons.org/licenses/by/ $4.0 /)$.
Abstract: Investigations on the application of Life Cycle Assessment (LCA) to the construction sector have shown that the environmental impact of construction products can be significantly reduced. To achieve this, the use of best available techniques and eco-innovation in production plants must be promoted. In this way, the use of finite natural resources can be replaced by waste generated in other production processes, preferably available locally, stimulating the creation of more sustainable products. Conducting a comparative LCA study between the traditional ceramic brick manufacturing process and the ceramic brick manufacturing process incorporating 'alperujo' (waste generated in the virgin oil extraction process), is an inevitable step to achieve the integration of circularity and eco-innovation in the production system of traditional ceramic materials, through the CML(Centrum voor Milieukunde Leiden) and IPCC(The Intergovernmental Panel on Climate Change) methodology. The obtained results suggest that the environmental benefits in this practice are very limited, even taking into account the contribution of different amounts of this waste to the production of bricks.

Keywords: circular economy; waste recycling; Life Cycle Assessment; olive pomace; brick industry

\section{Introduction}

Human influence on atmospheric quality has been increasing in recent years. If left unchecked, through the use of rigorous mitigation activities, climate change will increase the likelihood of severe, widespread, and irreversible impacts on people and ecosystems [1]. To truly minimize the risks of climate change, substantial and long-term reductions in greenhouse gas emissions are needed. Obviously, the ecological transition that is being pursued will involve the transformation of the country's major economic sectors [2].

In Europe, the construction sector is responsible for $40 \%$ of $\mathrm{CO}_{2}$ emissions, 30\% of raw material consumption, $20 \%$ of water consumption, $30 \%$ of waste generation, and a significant part of land occupation. The need to transform the construction sector involves reducing emissions of polluting gases through the use of new materials with a low or zero carbon footprint and, in addition, promoting the progress of the circular economy by reusing and incorporating materials from waste. Therefore, it is more than evident the necessary transition from the current linear production system to a production system based on a circular economy that allows the search for new alternatives with the main objective of curbing the consumption of natural reserves and the increase of $\mathrm{CO}_{2}$ emissions, as well as moving towards greater sustainability $[3,4]$.

On the other hand, the olive pomace (the so called 'alperujo') can represent up to 80\% of the olive production destined to olive oil mills for olive oil extraction [5]. According 
to data corresponding to the seasons comprised in the period 2015-2018, the production of olive oil and table olives was 1.2 million and 550,000 tonnes in Spain, representing approximately $40 \%$ and $20 \%$ of the world total [6-8]. This means that an estimated 11 million tonnes of olive pomace can be produced worldwide.

In this sense, the main objective of the present work is to carry out a comparative study of the Life Cycle Assessment (LCA) of traditional ceramic materials with respect to sustainable ceramic materials manufactured with olive pomace, waste generated in the virgin oil extraction process, which allows us to determine the global impact of the life cycle of the different products evaluated. For this purpose, the LCA of traditionally manufactured bricks was compared with the LCA of bricks in which 3, 7, and $10 \%$ of clay has been replaced by alperujo (ALP), based on the definition of the objective, scope, limits, and functional unit of the analysis, the performance of the Life Cycle Inventory (LCI) analysis, the Life Cycle Impact Assessment (LCIA) and, finally, the interpretation of the results obtained. The purpose of this is to establish the best environmentally sustainable options, to increase the amount of information available on the product and the process, and to identify points for improvement that can be proposed in the future. Olive pomace has been used because the main output of this by-product is its use as fuel with the consequent generation of a large amount of ash as final residue (between 4 and $8 \%$ of the waste burned). The common disposal of this biomass ash in landfills located next to power plants is an environmentally unattractive alternative [9-12].

\section{Methodology}

LCA is the most widely used methodology for seeking environmental solutions, minimizing the carbon footprint, and avoiding the production of impacts derived from the manufacture of products or services. LCA makes it possible to optimize inputs (materials and energy) and minimize outputs (waste and environmental impacts) of the activity under study. LCA technique has great potential in the study of the environmental impacts associated with the production of new materials [13] or conventional materials with applications in different sectors [14]. This methodology is regulated by the ISO 14040 and ISO 14044 standards $[15,16]$, and its main function is to establish a common basis from which to set inputs and outputs to the biosphere and technosphere through four steps for each approach: (i) Definition of the objective and scope; (ii) inventory analysis; (iii) impact assessment; and (iv) interpretation of the results. LCAs performed to the brick manufacturing industry have shown that the main environmental impacts occur due to energy consumption derived from the firing process $[17,18]$, finding values for climate change of fired clay bricks ranging from 132 to $295 \mathrm{~kg} \mathrm{CO}_{2}$ equivalent/tonne of brick, oscillations that are mainly attributed to the scope of the LCA, the characteristics of the firing process, and the quality of the bricks. There are few studies based on the use of LCA to determine the environmental benefits of waste incorporation in fired bricks [19-23].

\subsection{Definition of the Objective and Scope of the Study}

The objective of the present work has been to provide information on the environmental consequences of the brick production system from cradle to gate by comparing bricks produced in the traditional way with bricks in which certain amounts of clay have been substituted by olive pomace $(3,7$, and $10 \%$ by weight), for a reference time period of 100 years, measuring their impact using the IPCC and CML methodologies.

The cradle-to-gate approach analyzes the impact from the extraction of raw materials, the production of materials and product parts, and until the final product leaves the factory. The useful life and end-of-life stages are not the subject of study in this work.

In this Life Cycle Analysis, the industrial manufacturing of $1 \mathrm{~kg}$ of traditional brick was compared to $1 \mathrm{~kg}$ of brick incorporating 3, 7, and $10 \%$ by weight of olive pomace for a period of 100 years. Approximate dimensions of the samples were $117 \times 28 \times 17 \mathrm{~mm}$. The firing temperature defined in this analysis is $850^{\circ} \mathrm{C}$ because the bricks fired at these temperatures presented the best technological and thermal properties in previously developed works [23]. 
Figures 1 and 2 show images of the specimens produced in the laboratory before and after the sintering process, at the firing temperature of $850{ }^{\circ} \mathrm{C}$ and with different percentages of olive pomace added $(3,7$, and $10 \%)$.

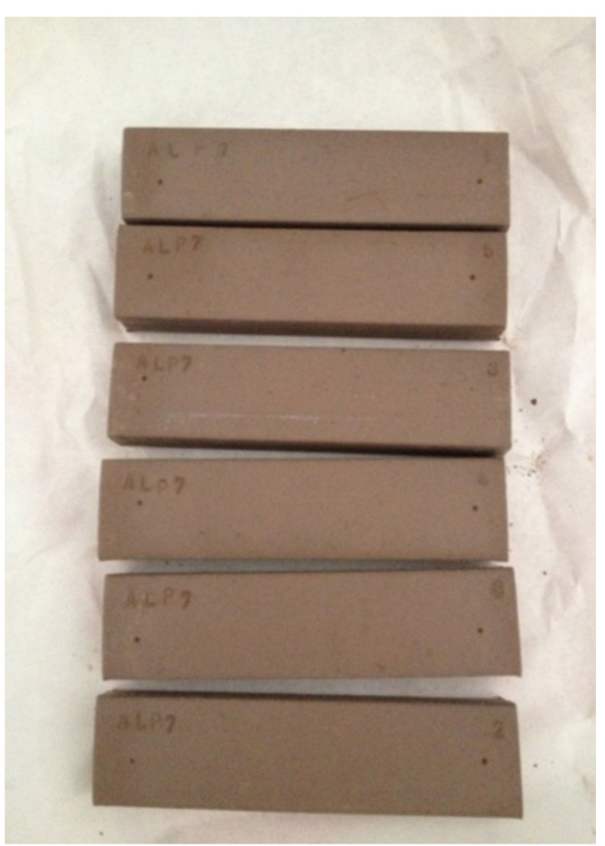

(a)

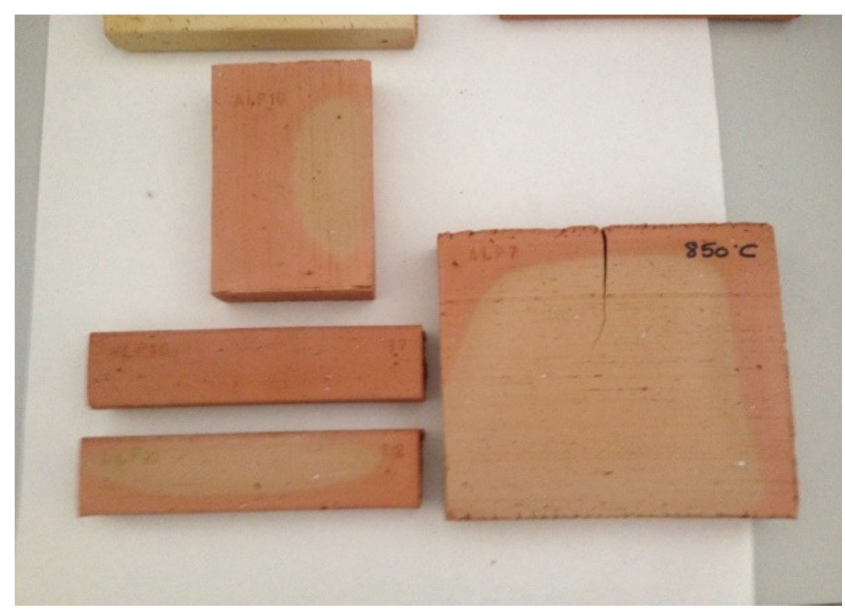

(b)

Figure 1. Specimens before (a) and after (b) sintering.

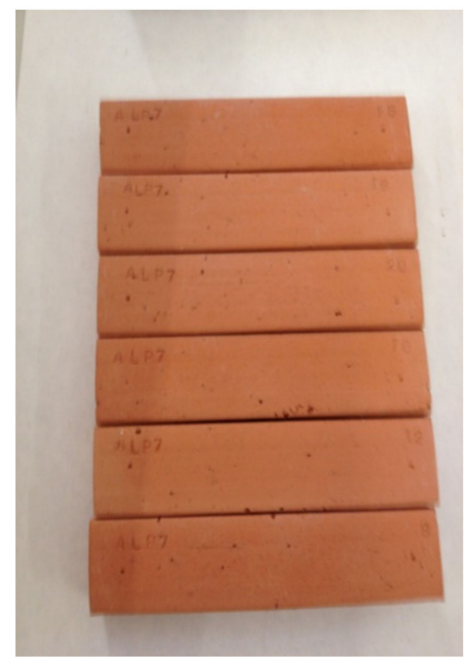

(a)

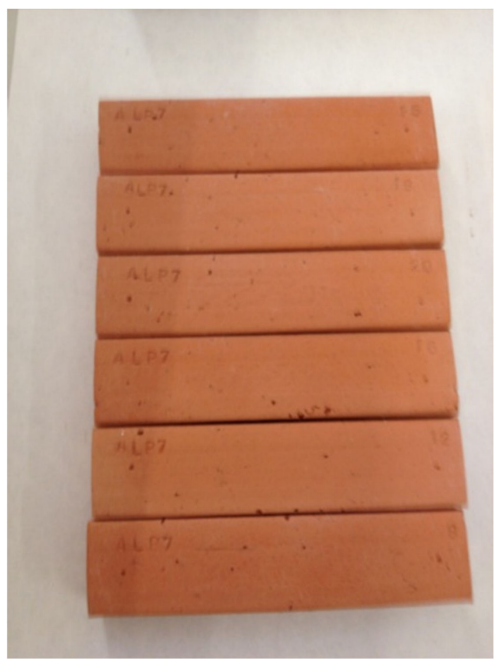

(b)

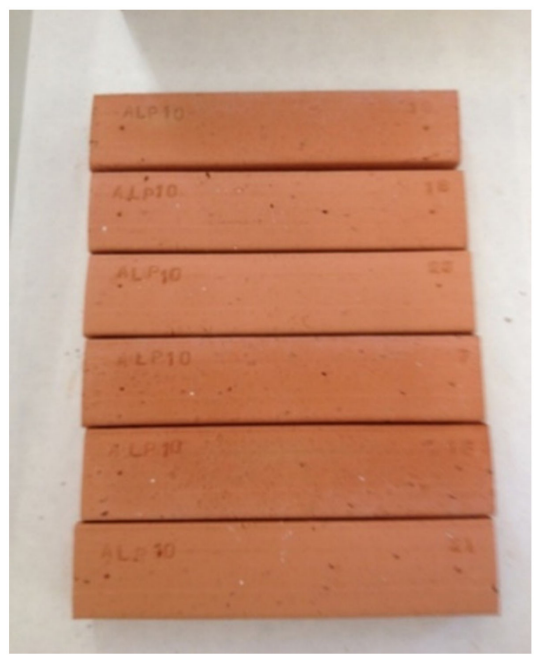

(c)

Figure 2. Specimens fired at $850{ }^{\circ} \mathrm{C}$; (a) 3\% ALP; (b) 7\% ALP; (c)10\% ALP.

\subsection{Life Cycle Inventory}

Table 1 shows the modelling performed in SIMAPRO for each of the processes involved in the manufacture of bricks by the traditional method and the manufacture of bricks with the addition of olive pomace, following the scheme represented in Figure 3, where the system limits taken as a reference in this study are indicated. 


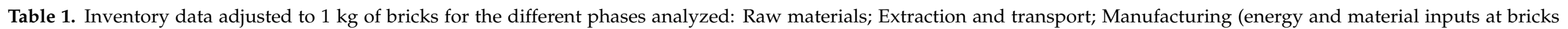
manufacturing plant) and Manufacturing (direct emissions associated with upstream processing).

\begin{tabular}{|c|c|c|c|c|c|c|}
\hline Elementary Flow & Units & $0 \%$ & $3 \%$ & $7 \%$ & $10 \%$ & LCIA Dataset \\
\hline \multicolumn{7}{|c|}{ Raw materials } \\
\hline Clay & $\mathrm{kg}$ & 1.11 & 107.48 & 103.04 & 0.9972 & Clay $\{$ GLO $\}$ | market for | Alloc Def, U \\
\hline Olive pomace & $\mathrm{kg}$ & - & 0.03324 & 0.07756 & 0.1108 & - \\
\hline Water & $\mathrm{kg}$ & 0.0272 & 0.0272 & 0.0272 & 0.0272 & Tap water $\{\mathrm{GLO}\}$ I market group for I Alloc Def, U \\
\hline Limestone, crushed, for mill & $\mathrm{kg}$ & 0.000396 & 0.000396 & 0.000396 & 0.000396 & $\begin{array}{l}\text { Limestone, crushed, for mill }\{\mathrm{GLO}\} \text { | market } \\
\text { for I Alloc Def, } \mathrm{U}\end{array}$ \\
\hline Lime, packed & $\mathrm{kg}$ & 0.0239 & 0.0239 & 0.0239 & 0.0239 & Lime, packed $\{$ GLO $\mid$ I market for I Alloc Def, U \\
\hline \multicolumn{7}{|c|}{ Extraction and transport } \\
\hline Lubricating oil & $\mathrm{kg}$ & 0.0000132 & 0.0000132 & 0.0000132 & 0.0000132 & Lubricating oil $\{$ GLO $\}$ market for $\mid$ Alloc Def, $U$ \\
\hline Extraction plant & $\mathrm{p}$ & 0.0000000002 & 0.0000000002 & 0.0000000002 & 0.0000000002 & $\begin{array}{c}\text { Clay pit infrastructure }\{\mathrm{GLO}\} \text { I market for I Alloc } \\
\text { Def, } U\end{array}$ \\
\hline Natural gas & $\mathrm{m}^{3}$ & 0.000047863 & 0.000047863 & 0.000047863 & 0.000047863 & $\begin{array}{l}\text { Natural gas, high pressure }\{\text { GLO\} I market group } \\
\text { for I Alloc Def, } U\end{array}$ \\
\hline Electricity & $\mathrm{kWh}$ & 0.00056 & 0.00056 & 0.00056 & 0.00056 & $\begin{array}{l}\text { Electricity, medium voltage }\{\mathrm{GLO}\} \text { | market } \\
\text { group for | Alloc Def, U }\end{array}$ \\
\hline Transport raw materials & kgkm & 50 & 50 & 50 & 50 & $\begin{array}{l}\text { Transport, freight, lorry 16-32 metric tonne, } \\
\text { EURO5 \{GLO\} I market for I Alloc Def, U }\end{array}$ \\
\hline Heavy fuel oil & $\mathrm{kg}$ & 0.000381 & 0.000381 & 0.000381 & 0.000381 & Heavy fuel oil $\{$ RoW $\}$ | market for | Alloc Def, $U$ \\
\hline \multicolumn{7}{|c|}{ Energy and material inputs at bricks manufacturing plant } \\
\hline Packaging film & $\mathrm{kg}$ & 0.000542 & 0.000542 & 0.000542 & 0.000542 & $\begin{array}{l}\text { Packaging film, low density polyethylene } \\
\{\text { GLO\} I market for I Alloc Def, U }\end{array}$ \\
\hline Polyethylene & $\mathrm{kg}$ & 0.000000858 & 0.000000858 & 0.000000858 & 0.000000858 & $\begin{array}{l}\text { Polyethylene, high density, granulate } \\
\{\text { GLO } \mid \text { I market for I Alloc Def, U }\end{array}$ \\
\hline EUR-flat pallet & $\mathrm{p}$ & 0.0000161 & 0.0000161 & 0.0000161 & 0.0000161 & EUR-flat pallet $\{$ GLO $\}$ I market for I Alloc Def, U \\
\hline Natural gas & $\mathrm{m}^{3}$ & 0.047576 & 0.033674 & 0.015139 & 0.001237 & $\begin{array}{c}\text { Natural gas, high pressure }\{\text { GLO }\} \text { I market group } \\
\text { for I Alloc Def, U }\end{array}$ \\
\hline
\end{tabular}


Table 1. Cont.

\begin{tabular}{|c|c|c|c|c|c|c|}
\hline Elementary Flow & Units & $0 \%$ & $3 \%$ & $7 \%$ & $10 \%$ & LCIA Dataset \\
\hline Sheet rolling & $\mathrm{kg}$ & 0.000000157 & 0.000000157 & 0.000000157 & 0.000000157 & $\begin{array}{c}\text { Sheet rolling, chromium steel }\{\text { GLO }\} \text { | market } \\
\text { for I Alloc Def, U }\end{array}$ \\
\hline Steel, low-alloyed, hot rolled & $\mathrm{kg}$ & 0.0000306 & 0.0000306 & 0.0000306 & 0.0000306 & $\begin{array}{l}\text { Steel, low-alloyed, hot rolled }\{\mathrm{GLO}\} \mid \text { market } \\
\text { for I Alloc Def, U }\end{array}$ \\
\hline Sheet rolling, steel & $\mathrm{kg}$ & 0.0000157 & 0.0000157 & 0.0000157 & 0.0000157 & $\begin{array}{c}\text { Sheet rolling, steel }\{\mathrm{GLO}\} \text { | market for | Alloc } \\
\text { Def, U }\end{array}$ \\
\hline Polystyrene, expandable & $\mathrm{kg}$ & 0.000352 & 0.000352 & 0.000352 & 0.000352 & $\begin{array}{c}\text { Polystyrene, expandable }\{\mathrm{GLO}\} \text { | market } \\
\text { for I Alloc Def, U }\end{array}$ \\
\hline Electricity & $\mathrm{kWh}$ & 0.047971 & 0.033954 & 0.015265 & 0.001248 & $\begin{array}{l}\text { Electricity, medium voltage }\{\mathrm{GLO}\} \mid \text { market } \\
\text { group for | Alloc Def, U }\end{array}$ \\
\hline \multicolumn{7}{|c|}{ Direct emissions associated with upstream processing } \\
\hline Nitrogen oxides & $\mathrm{kg}$ & 0.00026 & 0.00026 & 0.00026 & 0.00026 & Emissions to air-Nitrogen oxides \\
\hline Benzene & $\mathrm{kg}$ & 0.00000296 & 0.00000296 & 0.00000296 & 0.00000296 & Emissions to air-Benzene \\
\hline Sulfur dioxide & $\mathrm{kg}$ & 0.0000998 & 0.0000998 & 0.0000998 & 0.0000998 & Emissions to air-Sulfur dioxide \\
\hline \multirow{2}{*}{ Particulates } & $\mathrm{kg}$ & 0.000014 & 0.000014 & 0.000014 & 0.000014 & Emissions to air-Particulates, $<2.5 \mathrm{um}$ \\
\hline & $\mathrm{kg}$ & 0.00000468 & 0.00000468 & 0.00000468 & 0.00000468 & Emissions to air-Particulates, $>10 \mathrm{um}$ \\
\hline Formaldehyde & $\mathrm{kg}$ & 0.0000164 & 0.0000164 & 0.0000164 & 0.0000164 & Emissions to air-Formaldehyde \\
\hline Hydrogen fluoride & $\mathrm{kg}$ & 0.0000106 & 0.0000106 & 0.0000106 & 0.0000106 & Emissions to air-Hydrogen fluoride \\
\hline Water & $\mathrm{m}^{3}$ & 0.00001512 & 0.00001512 & 0.00001512 & 0.00001512 & Emissions to air-Water $/ \mathrm{m}^{3}$ \\
\hline Hydrogen chloride & $\mathrm{kg}$ & 0.0000122 & 0.0000122 & 0.0000122 & 0.0000122 & Emissions to air-Hydrogen chloride \\
\hline NMVOC & $\mathrm{kg}$ & 0.0000763 & 0.0000763 & 0.0000763 & 0.0000763 & $\begin{array}{l}\text { Emissions to air-NMVOC, non-methane } \\
\text { volatile organic compounds, unspecified }\end{array}$ \\
\hline Carbon dioxide, fossil & $\mathrm{kg}$ & 0.18 & 0.2336 & 0.3051 & 0.3588 & Emissions to air-Carbon dioxide, fossil \\
\hline Phenol & $\mathrm{kg}$ & 0.00000013 & 0.00000013 & 0.00000013 & 0.00000013 & Emissions to air-Phenol \\
\hline Water & $\mathrm{m}^{3}$ & 0.00008568 & 0.00008568 & 0.00008568 & 0.00008568 & Emissions to water-Water, RoW \\
\hline
\end{tabular}


Tradicional bricks scenario

Olive pomace bricks scenario

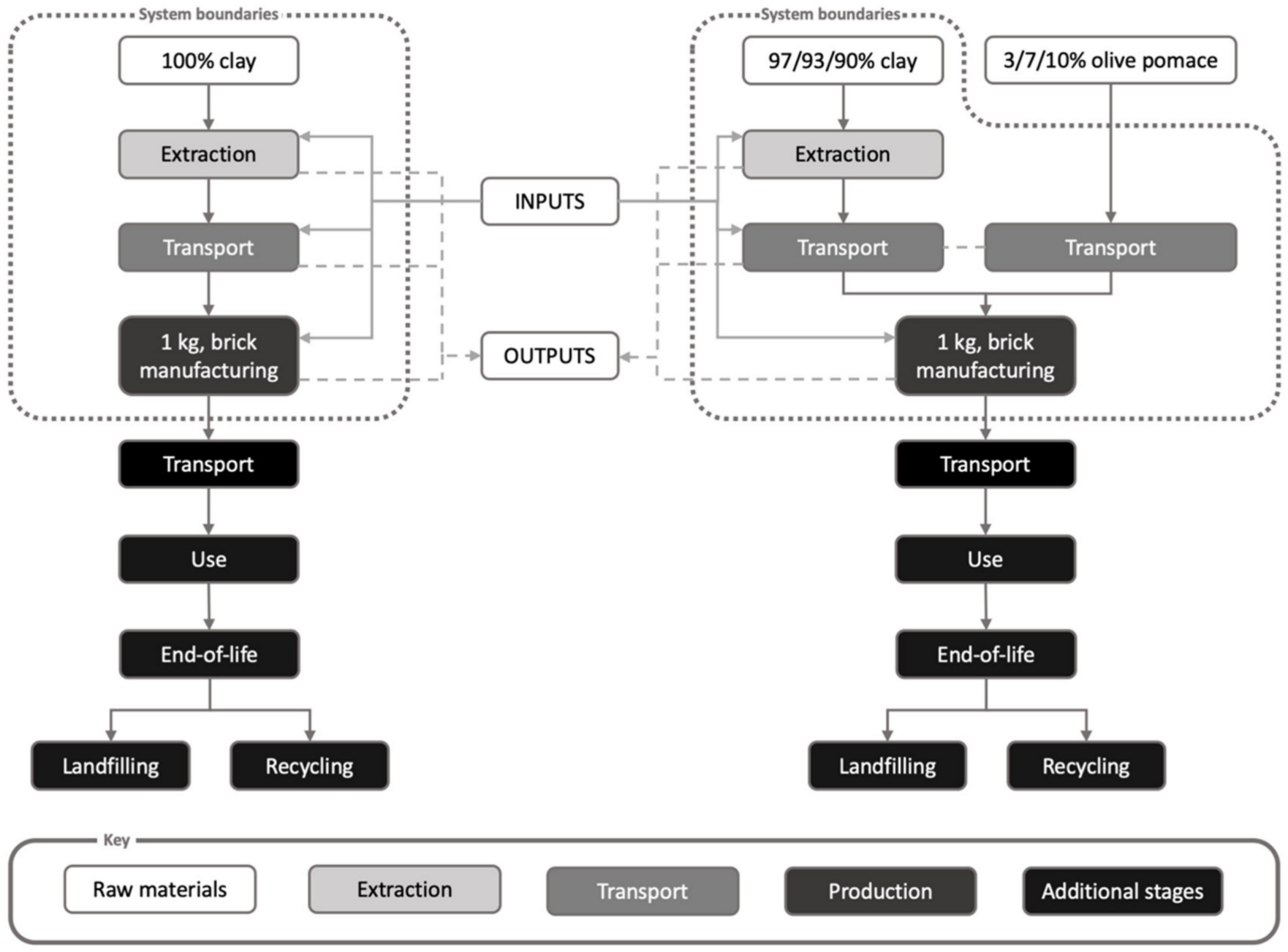

Figure 3. Life cycle flow chart of traditional bricks and bricks incorporating olive pomace in the different scenarios considered.

Figure 3 illustrates in schematic form the production process of traditional bricks on the left and sustainable bricks using waste on the right. In this study, the system boundaries have been considered from raw material extraction to brick production. During the 'Extraction', 'Transport', and 'Manufacture' phases, a series of inputs and outputs of material and energy will occur, which are illustrated in the diagram and which, to a greater or lesser extent, will be shared by both processes. The differential stage will be the 'Manufacture' stage, where the exothermic power of the olive pomace used allows the energy cost to be reduced during the sintering process.

Table 1 illustrates the inventory data for the 'Raw materials' phase. Table 1 lists the impacts associated with the extraction of natural clay, which are those related to the quarry operation, while the impacts attributable to the extraction of olive pomace are assigned to the main product of the olive oil extraction process and are not considered due to the residual nature of this material. The same table shows the inventory data for the 'Transport' phase of the raw materials to the mill. Emissions from the transport of the residue have been assimilated as the corresponding part of the clay it replaces. 
'Manufacturing' in Table 1 would be the last stage considered in this study. The data related to the manufacture of bricks in the factory by the traditional process as well as with bricks containing 3,7 , and $10 \%$ of olive pomace. It considers both energy consumption in the form of electricity, diesel, and natural gas in the brick manufacturing plant. Finally, Table 1 presents direct emissions in the form of $\mathrm{CO}_{2}, \mathrm{NO}_{\mathrm{x}}, \mathrm{SO}_{2}, \mathrm{HF}$, and $\mathrm{HCl}$ generated by the thermal transformation of the raw materials (natural clay and waste residue) during the firing process.

\subsection{Impact Assessment Methodology}

As a support tool for the analysis and quantification of impacts, the SIMAPRO 8.3.0.0.0 program of the company PRé Consultants was used. The ECOINVENT database was used in its version 3 [24], and two evaluation methodologies were used. The first methodology applied was IPCC, which characterizes emissions according to their global warming potential, through the valuation of greenhouse gases, including carbon dioxide, methane, nitrogen oxides, and chlorofluorocarbons, among others. The potential is evaluated in terms of $\mathrm{CO}_{2}$ eq, so that the emission of $1 \mathrm{~kg}$ of a particular greenhouse gas is expressed as the emission of $1 \mathrm{~kg}$ of carbon dioxide equivalent using established conversion factors. The second methodology used was CML 2000 V2.05, which analyzes abiotic resource depletion, acidification, eutrophication, global warming potential, ozone depletion, human toxicity, aquatic and terrestrial ecotoxicity, and photochemical oxidation as impact categories. The regional validity of the impact categories of the CML methodology is global, except for acidification and photochemical oxidation, which are based on European average values [25-27]. With respect to the latter methodology, the results have also been evaluated from a standardized point of view with respect to the environmental effects caused by an average European in one year [28].

\section{Results and Discussion}

Figure 4 and Table 2 illustrate the impacts obtained by IPCC-WGP-100 years for $1 \mathrm{~kg}$ of standard bricks produced from $100 \%$ natural clay and $1 \mathrm{~kg}$ of bricks produced with a 3,7 , and $10 \%$ by weight addition of olive pomace. The impact of the traditional system on global warming potential represents $260 \mathrm{~kg} \mathrm{CO}_{2}$ equivalent/tonne of bricks, a value comparable to those indicated by other authors such as [21-24], showing values of 221, 271, and $195 \mathrm{~kg} \mathrm{CO} 2$ equivalent/tonne of bricks, respectively. However, bricks with olive pomace have been shown to be environmentally less sustainable, showing higher climate change impact values than the traditional system. The increase in climate change potential of bricks with 3\% compared to bricks obtained by the traditional system is $19.2 \%$ (310 kg $\mathrm{CO}_{2}$ equivalent/tonne of bricks), increasing to $44.2 \%$ and $63 \%$ for bricks with 7 and $10 \%$ of olive pomace, respectively. The bricks with $3 \%$ of olive pomace have proven to be more environmentally sustainable than the rest of the bricks tested with the addition of wastewater residue for the established time period of 100 years.

Figure 5 shows the results obtained using the CML 2 baseline 2000 v2.05 methodology for a wider range of impact categories for traditional bricks. Figure 6 shows the impacts generated for the rest of the scenarios analyzed in this work in each of the ten selected environmental categories. Most of the impact, in all the scenarios tested, is attributable to the manufacturing phase, in particular the combustion of fossil fuels and the use of electricity during the firing process. The data on which these figures are based are shown in Table 3. 


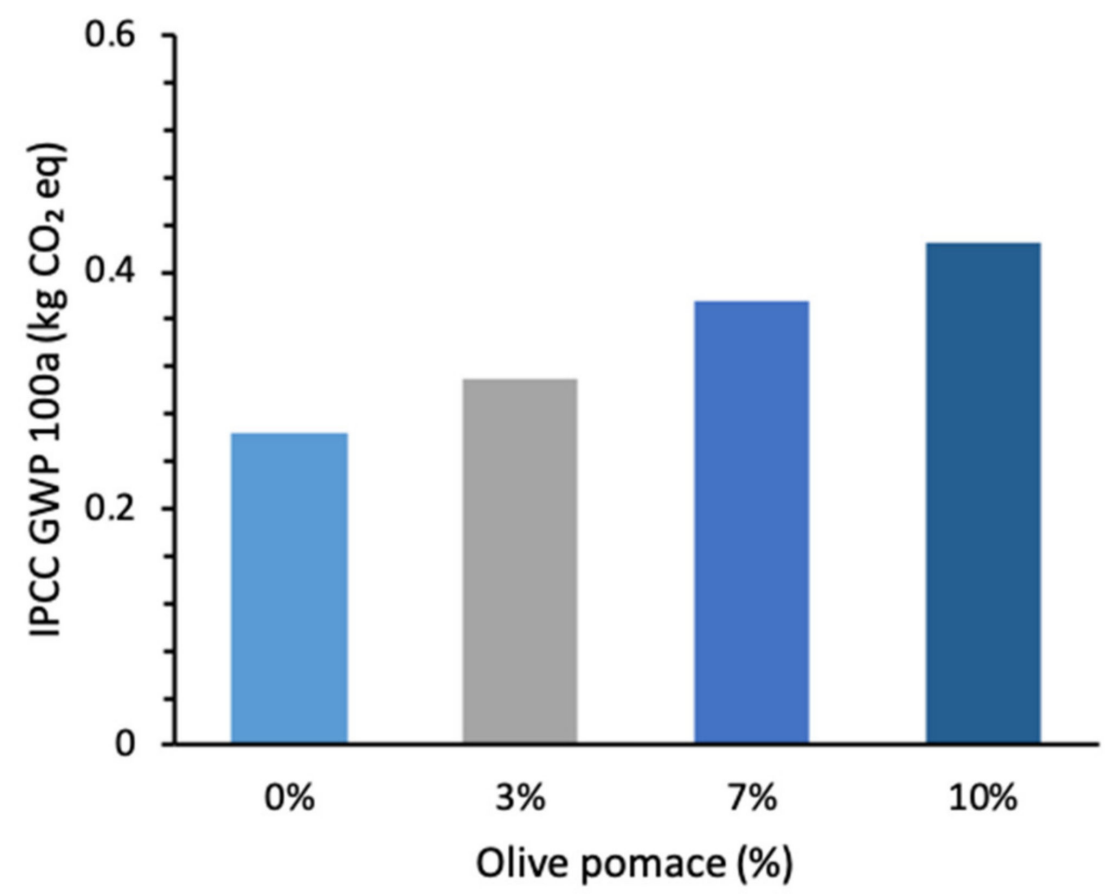

Figure 4. Climate change potential, 100 years $\left(\mathrm{kg} \mathrm{CO}_{2} \mathrm{eq}\right)$.

Table 2. Climate change potential, 100 years $\left(\mathrm{kg} \mathrm{CO}_{2} \mathrm{eq}\right)$.

\begin{tabular}{cc}
\hline Olive Pomace (\%) & IPCC GWP 100 a (kg CO $\mathbf{2}$ eq) \\
\hline 0 & 0.263 \\
3 & 0.310 \\
7 & 0.375 \\
10 & 0.424 \\
\hline
\end{tabular}

0\% OP

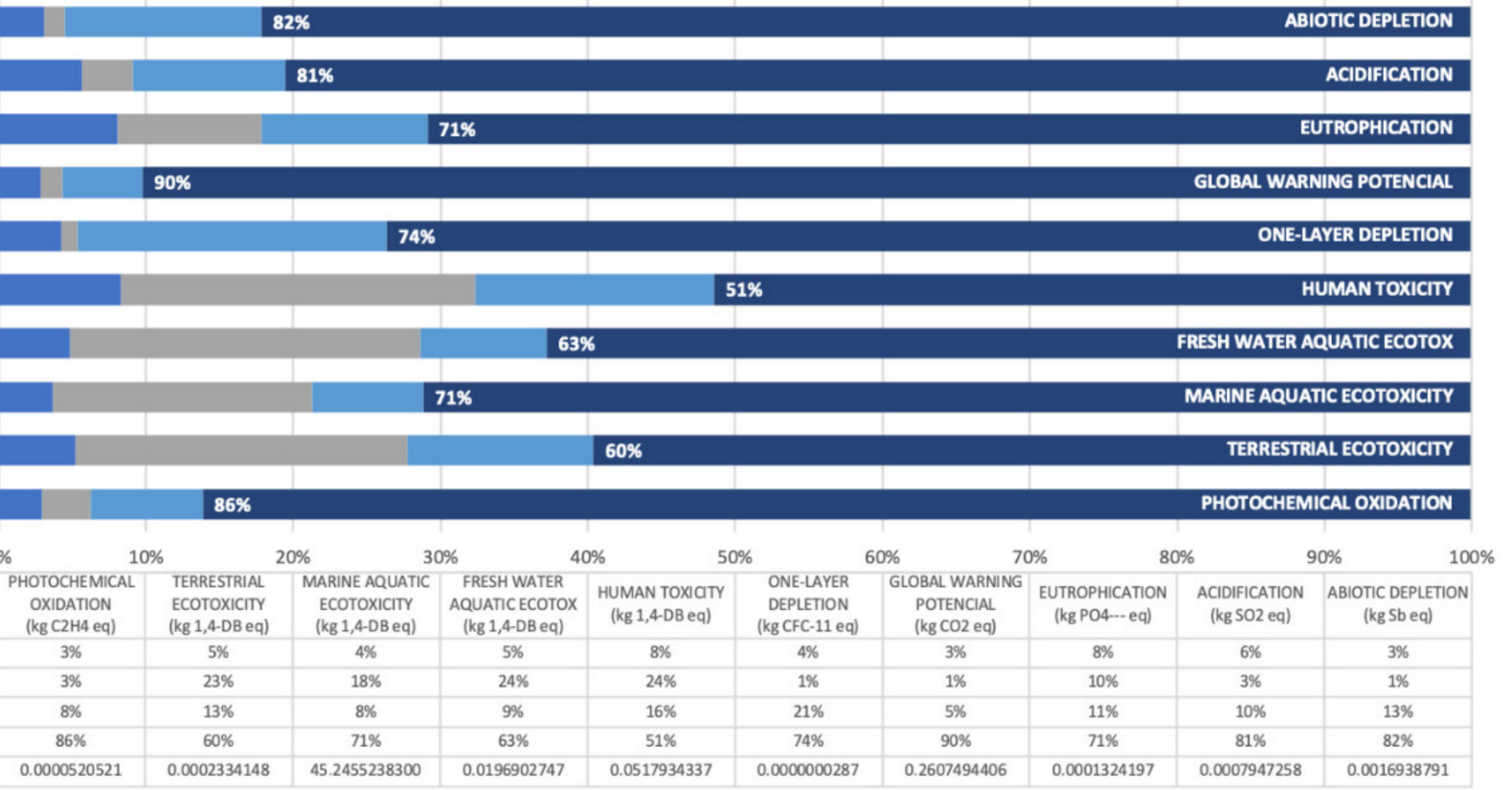

Figure 5. Impact distribution for each of the stages analyzed in characterization in traditional bricks. 


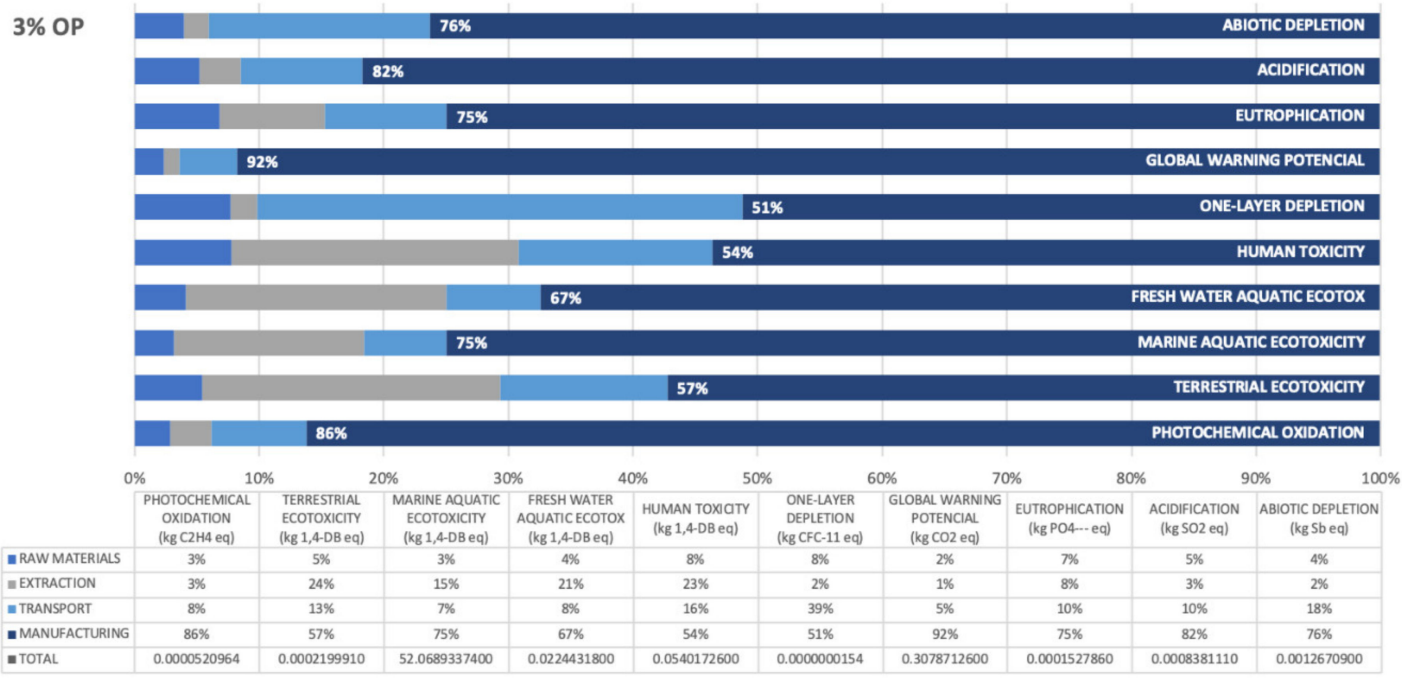

(a)

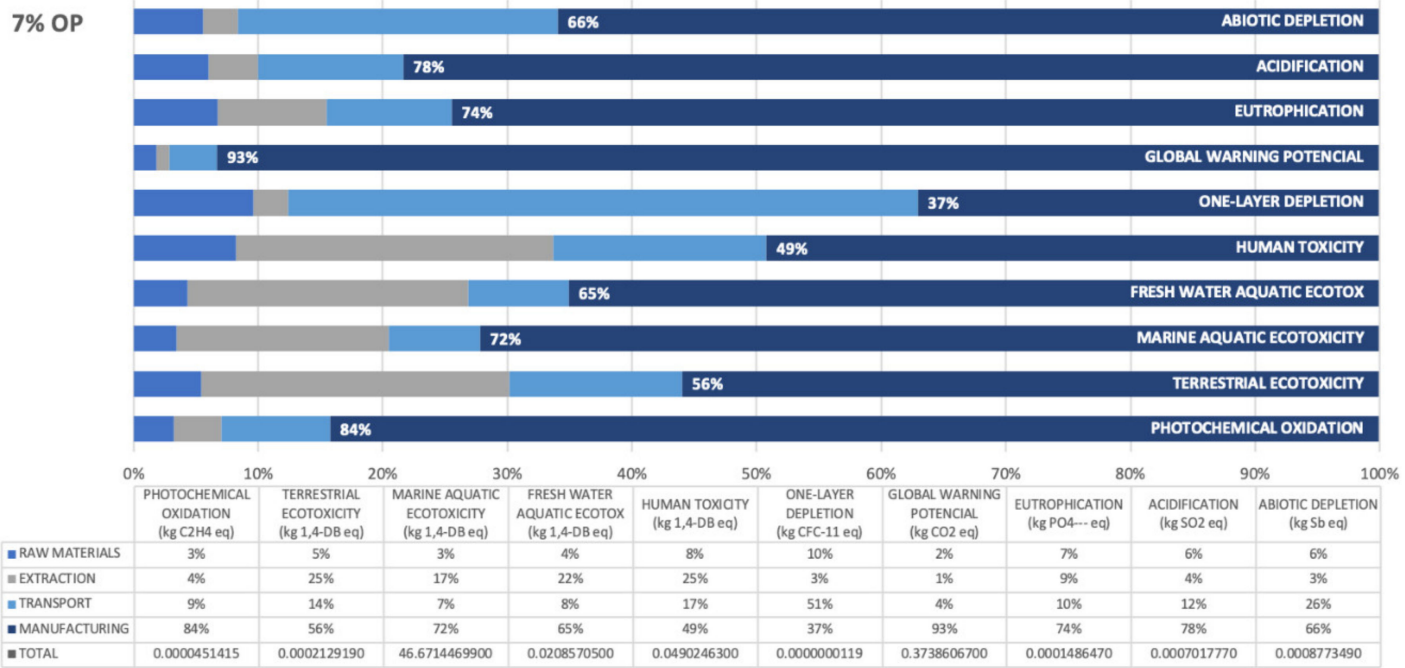

(b)

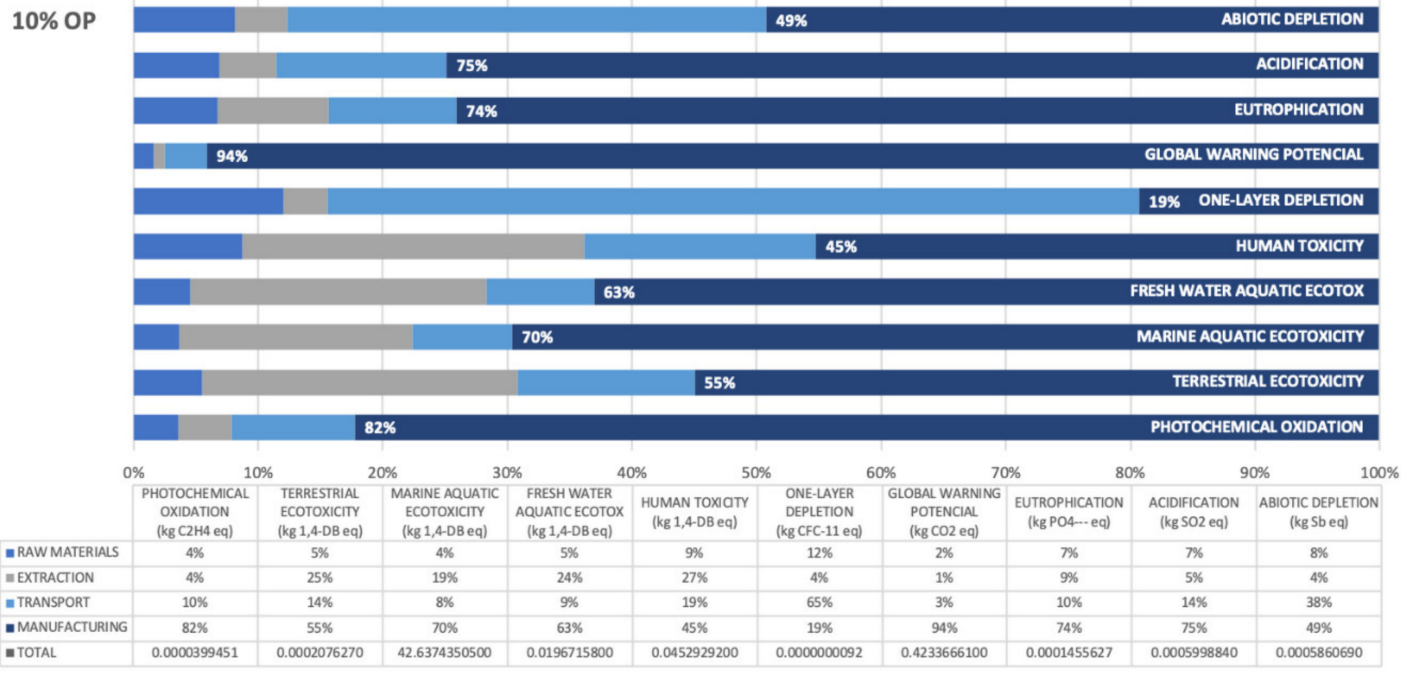

(c)

Figure 6. Impact distribution for each of the stages analyzed in characterization for bricks with olive pomace (a) bricks with $3 \%$ ALP; (b) bricks with 7\% ALP; and (c) bricks with 10\% ALP. 
Table 3. Characterized impacts associated with $1 \mathrm{~kg}$ of bricks incorporating $0,3,7$, and $10 \mathrm{wt} \%$ OP.

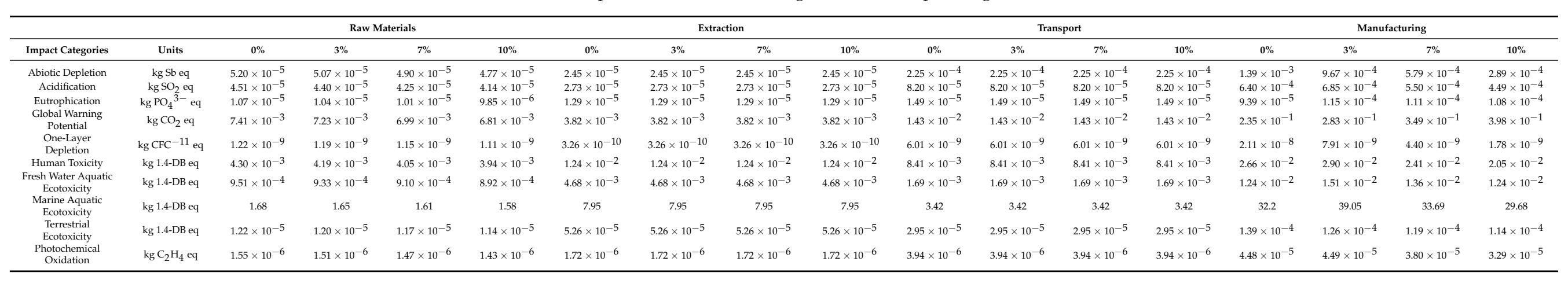


The manufacturing phase in the traditional system accounts for $90 \%$ of the "Global Warning Potential". Most of this impact (90\%) is due, in particular, to the combustion of fossil fuels and the use of electricity during the firing process. The raw materials, extraction and transportation phases account for 3, 1, and 5\%, respectively, for this impact category. The manufacturing phase is also the main cause of impact in all the other categories analyzed (between $51 \%$ and $86 \%$ ). The manufacturing phase accounts for $92 \%$ of the 'Global Warning Potential' for bricks with 3\% of olive pomace, reaching 93\% and 94\% for bricks containing $7 \%$ and $10 \%$ of this waste, respectively, as shown in Figure 6 . The environmental profile obtained for the bricks containing olive pomace is very similar to that observed for the traditional bricks, where most of the impact categories are dominated by the manufacturing phase, between $86 \%$ and $49 \%$ (Figure 6).

Of all the stages evaluated, it is in the extraction stage where the environmental benefit produced by the addition of olive pomace to the mixture is the greatest, assuming, as shown in Figures 5 and 6, both in the traditional system and in the bricks with olive pomace, only $1 \%$ of the "Global Warning Potential". Extraction is also the most beneficial step in the "Photochemical Oxidation", "Ozone Depletion", "Acidification" and "Abiotic Depletion" categories, with values ranging from 1 to $3 \%$. For the remaining categories ("Ecotoxicity", "Human Toxicity", and "Eutrophication"), the stage providing the greatest environmental benefit is that of raw materials, with values below $8 \%$.

Figure 7 shows the impact categories analyzed associated with the traditional brick manufacturing process, to which a reference value of $100 \%$ has been assigned in order to establish comparisons with the rest of the materials tested. The results show that the increase in the amount of olive pomace added generates a positive environmental impact with respect to the traditional process in the categories "Depletion of Abiotic Resources", due to the lower consumption of raw materials due to the addition of waste, "Depletion of the Ozone Layer" due to the fact that the incorporation of waste reduces the extent of endothermic reactions that occur during the manufacture of the ceramic product, thus reducing fuel consumption, "Terrestrial Ecotoxicity", due to the impact savings achieved by avoiding the dumping of the olive pomace, thus avoiding the leaching of potentially toxic species, and "Photochemical Oxidation", due to the decrease in the impacts derived from atmospheric emissions produced during the firing process.

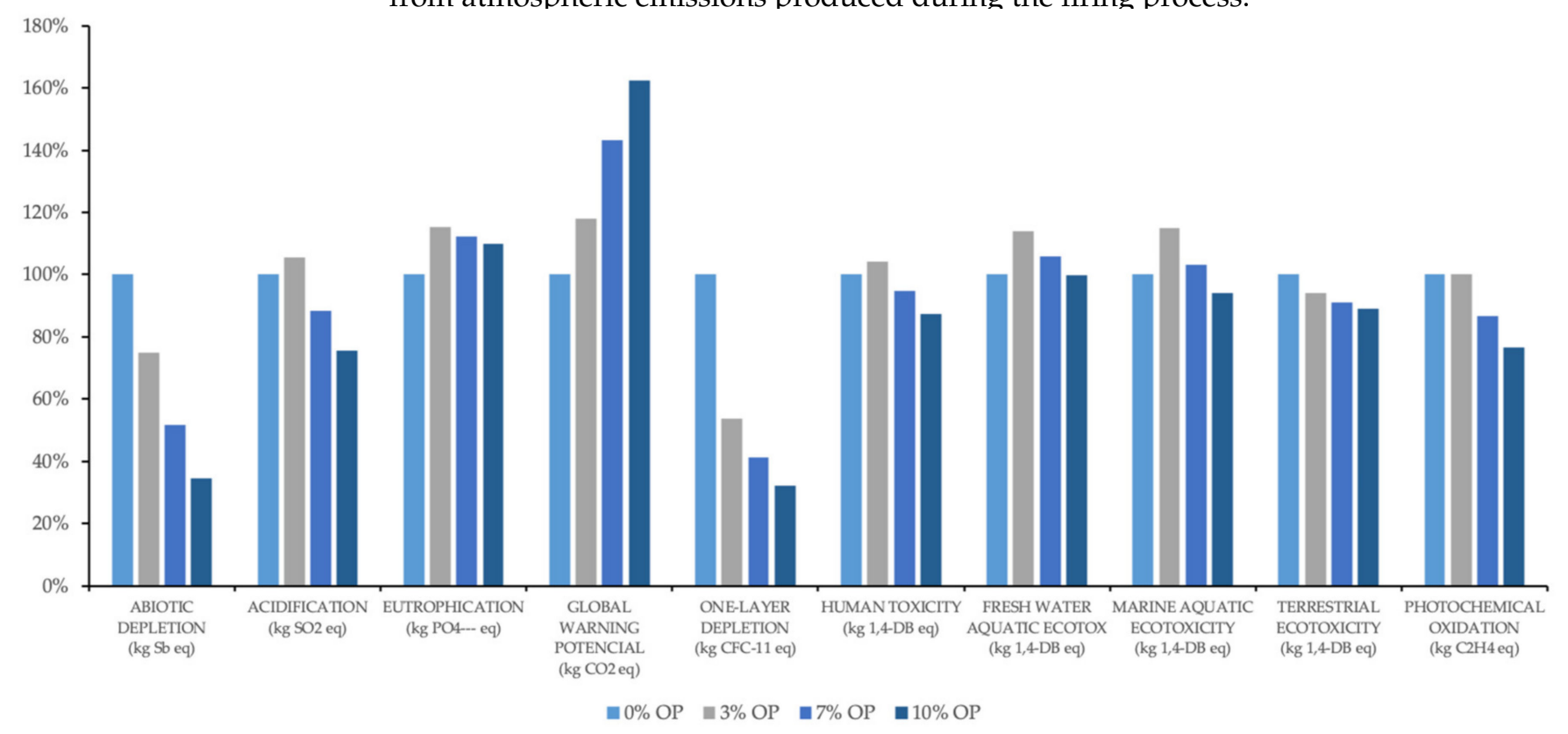

Figure 7. Impact categories analyzed using CML methodology. 
On the other hand, the addition of olive pomace worsens the environmental performance of the bricks with respect to the traditional process only for the categories "Eutrophication" and "Freshwater Ecotoxicity". It is observed that "Seawater Ecotoxicity" also worsens, although with a slight benefit for bricks with $10 \%$ olive pomace.

Comparing bricks with different proportions of added olive pomace, it can be seen that in all environmental categories, except "Global Warming Potential", there is a decrease in the environmental impact caused by increasing the amount of waste added.

It should be noted that the analysis performed with both methodologies for the impact category "Global Warming Potential" (GWP) provides results with a high degree of accuracy, practically $99.5 \%$.

Normalization is the calculation of the magnitude of a category indicator with respect to a reference information, i.e., it determines the relative magnitude of the LCIA results with respect to certain reference information in order to be able to interpret the LCA results in a simpler way. The criteria used to carry out the normalization are implicit in the methodologies that perform this step for impact assessment. Each impact assessment methodology uses its own reference system.

Figure 8 and Table 4 show the normalized results obtained by comparing the four scenarios investigated in this work. It can be seen that the impact category "Marine Aquatic Ecotoxicity" significantly exceeds the rest of the impact categories, a situation similar to that obtained by other authors [29-33]. These results may be due to the fact that the values provided by the normalization could be biased, either because the "Marine Aquatic Ecotoxicity" is too high or because the remaining impact categories are too low, given that the production of bricks with the addition of olive pomace is not considered an activity with high polluting repercussions for the marine environment.

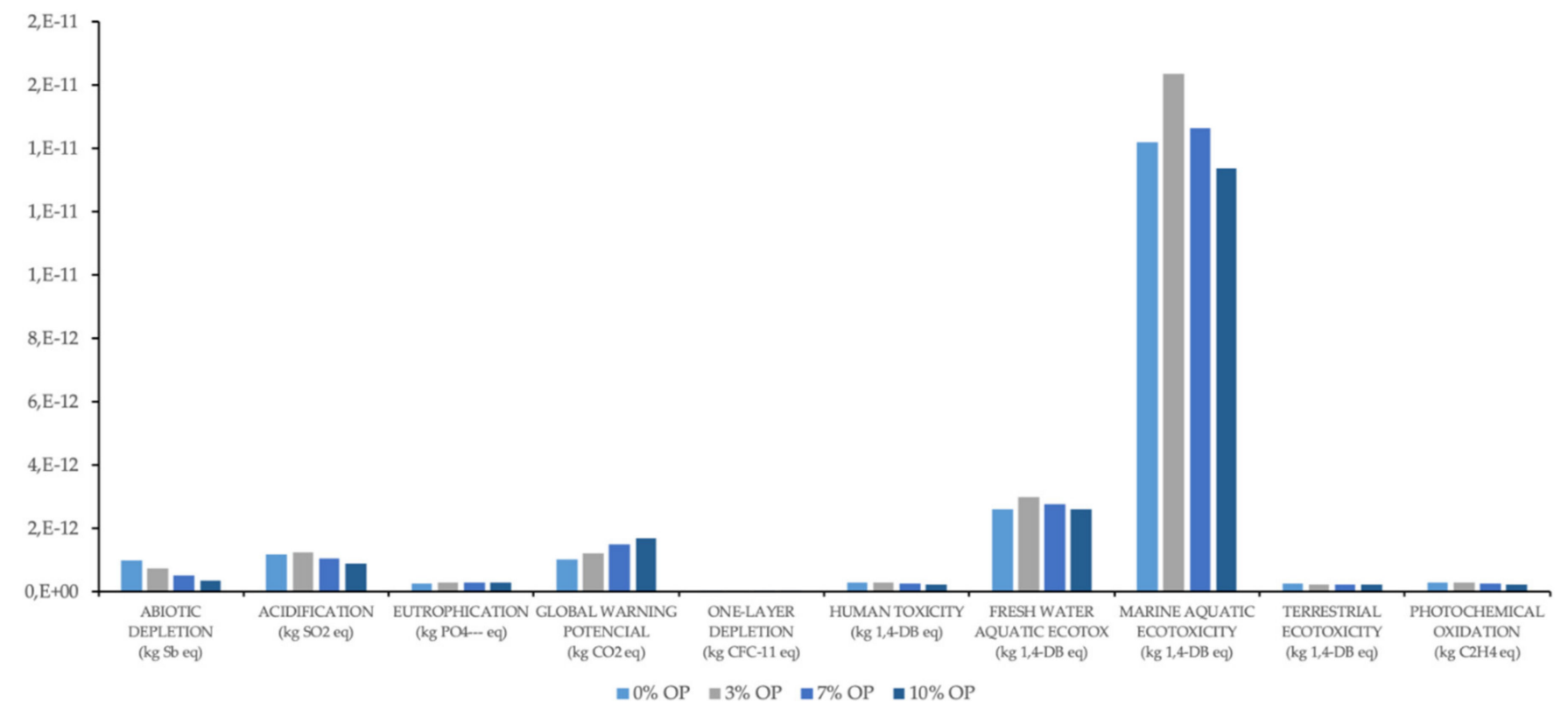

Figure 8. Impact categories analyzed using normalized CML. 
Table 4. Normalized impacts associated with $1 \mathrm{~kg}$ of bricks incorporating $0,3,7$, and $10 \mathrm{wt} \%$ OP.

\begin{tabular}{|c|c|c|c|c|c|c|c|c|c|c|c|c|c|c|c|c|c|}
\hline \multirow[b]{2}{*}{$\begin{array}{c}\text { Impact } \\
\text { Categories }\end{array}$} & \multirow[b]{2}{*}{ Units } & \multicolumn{4}{|c|}{ Raw Materials } & \multicolumn{4}{|c|}{ Extraction } & \multicolumn{4}{|c|}{ Transport } & \multicolumn{4}{|c|}{ Manufacturing } \\
\hline & & $0 \%$ & $3 \%$ & $7 \%$ & $10 \%$ & $0 \%$ & $3 \%$ & $7 \%$ & $10 \%$ & $0 \%$ & $3 \%$ & $7 \%$ & $10 \%$ & $0 \%$ & $3 \%$ & $7 \%$ & $10 \%$ \\
\hline Abiotic Depletion & $\mathrm{kg} \mathrm{Sb} \mathrm{eq}$ & $3.04 \times 10^{-14}$ & $2.97 \times 10^{-14}$ & $2.87 \times 10^{-14}$ & $2.79 \times 10^{-14}$ & $1.43 \times 10^{-14}$ & $1.43 \times 10^{-14}$ & $1.43 \times 10^{-14}$ & $1.43 \times 10^{-14}$ & $1.32 \times 10^{-13}$ & $1.32 \times 10^{-13}$ & $1.32 \times 10^{-13}$ & $1.32 \times 10^{-13}$ & $8.14 \times 10^{-13}$ & $5.65 \times 10^{-13}$ & $3.38 \times 10^{-13}$ & $1.69 \times 10^{-13}$ \\
\hline Acidification & $\mathrm{kg} \mathrm{SO}_{2}$ eq & $6.72 \times 10^{-14}$ & $6.56 \times 10^{-14}$ & $6.34 \times 10^{-14}$ & $6.17 \times 10^{-14}$ & $4.07 \times 10^{-14}$ & $4.07 \times 10^{-14}$ & $4.07 \times 10^{-14}$ & $4.07 \times 10^{-14}$ & $1.22 \times 10^{-13}$ & $1.22 \times 10^{-13}$ & $1.22 \times 10^{-13}$ & $1.22 \times 10^{-13}$ & $9.54 \times 10^{-13}$ & $1.02 \times 10^{-12}$ & $8.19 \times 10^{-13}$ & $6.69 \times 10^{-13}$ \\
\hline Eutrophication & $\mathrm{kg} \mathrm{PO}_{4}{ }^{3-}$ eq & $2.13 \times 10^{-14}$ & $2.08 \times 10^{-14}$ & $2.01 \times 10^{-14}$ & $1.96 \times 10^{-14}$ & $2.57 \times 10^{-14}$ & $2.57 \times 10^{-14}$ & $2.57 \times 10^{-14}$ & $2.57 \times 10^{-14}$ & $2.96 \times 10^{-14}$ & $2.96 \times 10^{-14}$ & $2.96 \times 10^{-14}$ & $2.96 \times 10^{-14}$ & $1.87 \times 10^{-13}$ & $2.28 \times 10^{-13}$ & $2.20 \times 10^{-13}$ & $2.15 \times 10^{-13}$ \\
\hline $\begin{array}{l}\text { Global Warning } \\
\text { Potencial }\end{array}$ & $\mathrm{kg} \mathrm{CO}_{2}$ eq & $2.93 \times 10^{-14}$ & $2.86 \times 10^{-14}$ & $2.77 \times 10^{-14}$ & $2.70 \times 10^{-14}$ & $1.51 \times 10^{-14}$ & $1.51 \times 10^{-14}$ & $1.51 \times 10^{-14}$ & $1.51 \times 10^{-14}$ & $5.65 \times 10^{-14}$ & $5.65 \times 10^{-14}$ & $5.65 \times 10^{-14}$ & $5.65 \times 10^{-14}$ & $9.32 \times 10^{-13}$ & $1.12 \times 10^{-12}$ & $1.38 \times 10^{-12}$ & $1.58 \times 10^{-12}$ \\
\hline $\begin{array}{l}\text { One-Layer } \\
\text { Delpetion }\end{array}$ & $\mathrm{kg} \mathrm{CFC}^{-11} \mathrm{eq}$ & $1.25 \times 10^{-15}$ & $1.21 \times 10^{-15}$ & $1.17 \times 10^{-15}$ & $1.13 \times 10^{-15}$ & $3.32 \times 10^{-16}$ & $3.32 \times 10^{-16}$ & $3.32 \times 10^{-16}$ & $3.32 \times 10^{-16}$ & $6.13 \times 10^{-15}$ & $6.13 \times 10^{-15}$ & $6.13 \times 10^{-15}$ & $6.13 \times 10^{-15}$ & $2.16 \times 10^{-14}$ & $8.07 \times 10^{-15}$ & $4.49 \times 10^{-15}$ & $1.82 \times 10^{-15}$ \\
\hline Human Toxicity & kg 1.4-DB eq & $2.29 \times 10^{-14}$ & $2.23 \times 10^{-14}$ & $2.16 \times 10^{-14}$ & $2.10 \times 10^{-14}$ & $6.62 \times 10^{-14}$ & $6.62 \times 10^{-14}$ & $6.62 \times 10^{-14}$ & $6.62 \times 10^{-14}$ & $4.47 \times 10^{-14}$ & $4.47 \times 10^{-14}$ & $4.47 \times 10^{-14}$ & $4.47 \times 10^{-14}$ & $1.42 \times 10^{-13}$ & $1.54 \times 10^{-13}$ & $1.28 \times 10^{-13}$ & $1.09 \times 10^{-13}$ \\
\hline $\begin{array}{c}\text { Fresh Water } \\
\text { Aquatic Ecotox }\end{array}$ & kg 1.4-DB eq & $1.26 \times 10^{-13}$ & $1.24 \times 10^{-13}$ & $1.21 \times 10^{-13}$ & $1.19 \times 10^{-14}$ & $6.23 \times 10^{-14}$ & $6.23 \times 10^{-13}$ & $6.23 \times 10^{-13}$ & $6.23 \times 10^{-13}$ & $2.25 \times 10^{-13}$ & $2.25 \times 10^{-13}$ & $2.25 \times 10^{-13}$ & $2.25 \times 10^{-13}$ & $1.64 \times 10^{-12}$ & $2.01 \times 10^{-12}$ & $1.80 \times 10^{-12}$ & $1.65 \times 10^{-12}$ \\
\hline $\begin{array}{l}\text { Marine Aquatic } \\
\text { Ecotoxicity }\end{array}$ & kg 1.4-DB eq & $5.27 \times 10^{-13}$ & $5.18 \times 10^{-13}$ & $5.06 \times 10^{-13}$ & $4.97 \times 10^{-13}$ & $2.50 \times 10^{-12}$ & $2.50 \times 10^{-12}$ & $2.50 \times 10^{-12}$ & $2.50 \times 10^{-12}$ & $1.07 \times 10^{-12}$ & $1.07 \times 10^{-12}$ & $1.07 \times 10^{-12}$ & $1.07 \times 10^{-12}$ & $1.01 \times 10^{-11}$ & $1.23 \times 10^{-11}$ & $1.06 \times 10^{-11}$ & $9.32 \times 10^{-12}$ \\
\hline $\begin{array}{l}\text { Photochemical } \\
\text { Oxidation }\end{array}$ & $\mathrm{kg} \mathrm{C}_{2} \mathrm{H}_{4}$ eq & $8.49 \times 10^{-15}$ & $8.31 \times 10^{-15}$ & $8.05 \times 10^{-15}$ & $7.86 \times 10^{-15}$ & $9.43 \times 10^{-15}$ & $9.43 \times 10^{-15}$ & $9.43 \times 10^{-15}$ & $9.43 \times 10^{-15}$ & $2.16 \times 10^{-14}$ & $2.16 \times 10^{-14}$ & $2.16 \times 10^{-14}$ & $2.16 \times 10^{-14}$ & $2.46 \times 10^{-13}$ & $2.47 \times 10^{-13}$ & $2.09 \times 10^{-13}$ & $1.80 \times 10^{-13}$ \\
\hline
\end{tabular}




\section{Conclusions}

To prevent the production of materials from affecting natural resources, it is necessary to promote the use of the best available techniques, as well as innovation in production plants to replace, as far as possible, the use of finite natural resources with the waste generated in the different production processes, closing product cycles. This implies a firm commitment to reuse and recycling, and always minimizing the transport of raw materials and products, promoting the use of available resources in local areas.

The ceramics industry generates impacts throughout its entire production cycle, from the extraction of the necessary resources to the final distribution of the product to the customer and the disposal of the waste generated. The LCA conducted in this research examines the brick production system from cradle to gate by comparing bricks produced in the traditional way with bricks to which olive pomace (alperujo) has been added at 3 , 7 , and $10 \%$ by weight, measuring its impact using IPCC and CML methodologies for a reference time of 100 years.

Regarding the potential environmental benefits of the incorporation of olive pomace into fired bricks, it has been observed that the stages of the life cycle that benefit the most are the "raw material" and "extraction" stages. Extraction accounts for only $1 \%$ of the "Global Warning Potential" in both the traditional system and in bricks with olive pomace, and between 1 and 3\% for the environmental categories of "Photochemical Oxidation", "Ozone Depletion", "Acidification", and "Abiotic Depletion". The raw materials stage is the most environmentally beneficial in the "Ecotoxicity", "Human Toxicity", and "Eutrophication" categories, with values below $8 \%$, mainly due to a reduced need for feedstock, which is covered by the waste added.

The least benefited stage would be the manufacturing, mainly due to the atmospheric emissions produced by the thermal decomposition of the raw materials used and the energy intensity required for the process, which, although reduced in some categories due to the exothermic decomposition of the olive pomace, is still high. The manufacturing phase in the traditional system accounts for $90 \%$ of the "Global Warning Potential", $92 \%$ of the "Global Warning Potential" for bricks with 3\% alpeorujo, and 93\% and $94 \%$ for bricks with 7 and $10 \mathrm{wt} \%$ olive pomace, respectively. The environmental profile for the other categories is similar, with no significant variations due to the olive pomace addition.

On the other hand, transport is not modified with the incorporation of the residue compared to the traditional system, as the emissions from the transport of the olive pomace have been assimilated as the corresponding part of the raw material it replaces.

The aggregate analysis carried out shows that the benefits of incorporating olive pomace into bricks are very limited. Although olive pomace bricks performed better in the categories of Abiotic Resource Depletion, Ozone Depletion, and Terrestrial Ecotoxicity, this was offset by higher impacts in the categories of Acidification, Eutrophication, Human Toxicity, Freshwater and Seawater Ecotoxicity, and Photochemical Oxidation. Finally, the higher amount of added olive pomace results in a slight decrease in environmental impact in all environmental categories except "Global Warming Potential".

In short, construction is one of the least environmentally sustainable sectors, generating high environmental costs, mainly due to the high consumption of resources and the large amount of waste produced. The brick manufacturing process has a negative environmental impact and is one of the most used materials on a daily basis in the construction sector worldwide. For this reason, the brick industry should implement technologies that consume less energy or use other more renewable energy sources. In this sense, an essential aspect is the use of alternative raw materials that can replace clay, such as waste, thus meeting the required technological properties while significantly reducing the environmental impact. 
Author Contributions: Conceptualization, A.B.L.-G. and T.C.-P.; methodology, A.B.L.-G. and M.U.R.; software, M.U.-R.; validation, A.B.L.-G. and M.U.-R.; formal analysis, A.B.L.-G.; investigation, A.B.L.-G. and M.U.-R.; resources, C.J.C.-C.; data curation, M.U.-R.; writing-original draft preparation, A.B.L.-G.; writing-review and editing, J.M.M.-M.; visualization, N.M.F.A.; supervision, T.C.-P.; project administration, C.M.-G.; funding acquisition, C.M.-G. All authors have read and agreed to the published version of the manuscript.

Funding: This research was conducted as a part of the EcoMetal Project (PID2019-109520RB-I00), "Can industrial and mining metalliferous wastes produce green lightweight aggregates? Applying the Circular Economy", funded by the Spanish Ministry of Economy and Competitiveness and FEDER (MINECO-FEDER).

Institutional Review Board Statement: Not applicable.

Informed Consent Statement: Not applicable.

Data Availability Statement: Not applicable.

Acknowledgments: The authors gratefully acknowledge this support. The authors also gratefully acknowledge the technical and human support provided by CICT of the University of Jaén and the University of Málaga (UJA, MINECO, Junta de Andalucía, FEDER).

Conflicts of Interest: The authors declare no conflict of interest.

\section{References}

1. Pascal, M.; Corso, M.; Chanel, O.; Declercq, C.; Badaloni, C.; Cesaroni, G.; Henschel, S.; Meister, K.; Haluza, D.; Martin-Olmedo, P.; et al. Assessing the public health impacts of urban air pollution in 25 European cities: Results of the Aphekom project. Sci. Total Environ. 2013, 449, 390-400. [CrossRef]

2. Velasco, P.M.; Ortíz, M.M.; Giró, M.M. Fired clay bricks manufactured by adding wastes as sustainable construction material—A review. Constr. Build. Mater. 2014, 63, 97-107. [CrossRef]

3. Zhang, L. Production of bricks from waste materials-A review. Constr. Build. Mater. 2013, 47, 643-655. [CrossRef]

4. Monteiro, S.N.; Vieira, C.M.F. On the production of fired clay bricks from waste materials: A critical update. Constr. Build. Mater. 2014, 68, 599-610. [CrossRef]

5. Agencia de Gestión Agraria y Pesquera de Andalucía, Consejería de Agricultura, Pesca Y Desarrollo. Evaluación de la Producción y Usos de Los Subproductos de Las Agroindustrias del Olivar en Andalucía. 2015. Available online: http:/ / www.juntadeandalucia.es / agriculturaypesca / observatorio/servlet/FrontController?action=DownloadS\&table=1103 0\&element=1585171\&field=DOCUMENTO (accessed on 22 September 2020).

6. Consejería de Agricultura, Pesca y Desarrollo Rural. Aforo de Producción de olivar en Andalucía-Campaña 2017-2018. Available online: http:/ / www.juntadeandalucia.es/export/drupaljda/Presentación_OLIVAR_2017-2018.pdf (accessed on 26 June 2020).

7. Consejería de Agricultura, Pesca y Desarrollo Rural. Aforo de Producción de Olivar en Andalucía-Campaña 2016-2017. Available online: http:/ / www.juntadeandalucia.es/export/drupaljda/AFORO_OLIVAR_2016-2017.pdf (accessed on 26 June 2020).

8. Consejería de Agricultura, Pesca y Desarrollo Rural. Aforo de Producción de Olivar en Andalucía-Campaña 2015-2016. Available online: http:/ / www.juntadeandalucia.es/export/drupaljda/AFORO_2015-2016.pdf (accessed on 26 June 2020).

9. Nastri, A.; Ramieri, N.; Abdayem, R.; Piccaglia, R.; Marzadori, C.; Ciavatta, C. Olive pulp and its effluents suitability for soil amendment. J. Hazard. Mater. 2006, 138, 211-217. [CrossRef]

10. Alburquerque, J.; Gonzalvez, J.; Garcia, D.; Cegarra, J. Effects of a compost made from the solid by-product ("alperujo") of the two-phase centrifugation system for olive oil extraction and cotton gin waste on growth and nutrient content of ryegrass (Lolium perenne L.). Bioresour. Technol. 2007, 98, 940-945. [CrossRef]

11. Borja, R.; Raposo, F.; Rincón, B. Treatment technologies of liquid and solid wastes from two-phase olive oil mills. Grasas Aceites 2006, 57, 32-46. [CrossRef]

12. Alburquerque, J.A.; Gonzálvez, J.; García, D.; Cegarra, J. Agrochemical characterisation of "alperujo", a solid by-product of the two-phase centrifugation method for olive oil extraction. Bioresour. Technol. 2004, 91, 195-200. [CrossRef]

13. Khosravani, M.R.; Reinicke, T. On the environmental impacts of 3D printing technology. Appl. Mater. Today 2020, 20, 100689. [CrossRef]

14. Samani, P.; Van Der Meer, Y. Life cycle assessment (LCA) studies on flame retardants: A systematic review. J. Clean. Prod. 2020, 274, 123259. [CrossRef]

15. ISO. ISO 14040. In Environmental Management_Life Cycle Assessment_Principles and Framework; ISO: Geneva, Switzerland, 2006.

16. ISO. ISO 14044. In Environmental Management_Life Cycle Assessment_Requirements and Guidelines; ISO: Geneva, Switzerland, 2006.

17. Koroneos, C.; Dompros, A. Environmental assessment of brick production in Greece. Build. Environ. 2007, 42, 2114-2123. [CrossRef] 
18. Bribián, I.Z.; Capilla, A.V.; Usón, A.A. Life cycle assessment of building materials: Comparative analysis of energy and environmental impacts and evaluation of the eco-efficiency improvement potential. Build. Environ. 2011, 46, 1133-1140. [CrossRef]

19. Galán-Arboledas, R.J.; De Diego, J. Álvarez; Dondi, M.; Bueno, S. Energy, environmental and technical assessment for the incorporation of EAF stainless steel slag in ceramic building materials. J. Clean. Prod. 2017, 142, 1778-1788. [CrossRef]

20. Almeida, M.I.; Dias, A.C.; Demertzi, M.; Arroja, L. Contribution to the development of product category rules for ceramic bricks. J. Clean. Prod. 2015, 92, 206-215. [CrossRef]

21. Pérez-Hernández, A.; López-Aguilar, H.A.; Huerta-Reynoso, E.A.; Gomez, J.A.; Olivarez-Ramírez, J.M.; Duarte-Moller, A. Life cycle assessment of regional brick manufacture. Mater. Constr. 2016, 66, e085. [CrossRef]

22. Kulkarni, N.G.; Rao, A.B. Carbon footprint of solid clay bricks fired in clamps of India. J. Clean. Prod. 2016, 135, 1396-1406. [CrossRef]

23. Díaz-García, A.; Martínez-García, C.; Cotes-Palomino, T. Properties of Residue from Olive Oil Extraction as a Raw Material for Sustainable Construction Materials. Part I Physical Properties. Mater. 2017, 10, 100. [CrossRef]

24. Weidema, B.P.; Bauer, C.; Hischier, R.; Mutel, C.; Nemecek, T.; Reinhard, J.; Vadenbo, C.O.; Wernet, G. Overview and Methodology. Data Quality Guideline for the Ecoinvent Database Version 3, 1st ed.; Ecoinvent Report 1(v3); The Ecoinvent Centre: St. Gallen, Switzerland, 2013; Available online: https:/ / www.ecoinvent.org/files/dataqualityguideline_ecoinvent_3_20130506.pdf (accessed on 14 September 2020).

25. Bates, B.C.; Kundzewicz, Z.W.; Wu, S.; Palutikof, J.P. Climate Change and Water. In Technical Paper of the Intergovernmental Panel on Climate Change; IPCC: Geneva, Switzerland, 2008; p. 210.

26. Watson, R.T.; Zinyowera, M.C.; Moss, R.H. Technologies, Policies and Measures for Mitigating Climate Change. In Technical Paper of the Intergovernmental Panel on Climate Change; IPCC: Geneva, Switzerland, 1996; p. 84.

27. European Commission. ILCD Handbook: Analysing of Existing Environmental Impact Assessment Methodologies for Use in Life Cycle Assessment, 1st ed.; Institute for Environment and Sustainability: Luxembourg, 2010.

28. Gorrée, M.; Heijungs, R.; Huppes, G.; Kleijn, R.; Koning, A.; de Oers, L.; van Wegener Sleeswijk, A.; Suh, S.; Udo de Haes, H.A.; Bruijn, H.; et al. Handbook on Life Cycle Assessment. Operational Guide to the ISO Standards. I: LCA in Perspective. IIa: Guide. IIb: Operational Annex. III: Scientific Background; Kluwer Academic Publishers: Dordrecht, The Netherlands, 2002; 692p, ISBN 1-4020-0228-9.

29. Heijungs, R.; Guinée, J.; Kleijn, R.; Rovers, V. Bias in normalization: Causes, consequences, detection and remedies. Int. J. Life Cycle Assess. 2006, 12, 211-216. [CrossRef]

30. Pulselli, R.M.; Ridolfi, R.; Rugani, B.; Tiezzi, E. Application of life cycle assessment to the production of man-made crystal glass. Int. J. Life Cycle Assess. 2009, 14, 490-501. [CrossRef]

31. Konstantzos, G.E.; Malamis, D.; Sotiropoulos, A.; Loizidou, M. Environmental profile of an innovative household biowaste dryer system based on Life Cycle Assessment. Waste Manag. Res. 2018, 37, 48-58. [CrossRef]

32. Behrooznia, L.; Sharifi, M.; Alimardani, R.; Mousavi-Avval, S.H. Sustainability analysis of landfilling and composting-landfilling for municipal solid waste management in the north of Iran. J. Clean. Prod. 2018, 203, 1028-1038. [CrossRef]

33. Krzyżaniak, M.; Stolarski, M.J.; Szczukowski, S.; Tworkowski, J. Life Cycle Assessment of New Willow Cultivars Grown as Feedstock for Integrated Biorefineries. BioEnergy Res. 2015, 9, 224-238. [CrossRef] 